\begin{tabular}{|c|c|c|}
\hline \begin{tabular}{|l} 
\\
EXCELLENT \\
PUBLISHERS
\end{tabular} & $\begin{array}{c}\text { International Journal of Current Research in } \\
\text { Biosciences and Plant Biology } \\
\text { ISSN: 2349-8080 (Online) } \bullet \text { Volume } 3 \bullet \text { Number } 9 \text { (September-2016) } \\
\text { Journal homepage: } \text { www.jicrbp.com }\end{array}$ & \\
\hline
\end{tabular}

\title{
State, Ecological Characterization and Strategies of Sustainable Management of Plant Formations in the Mayo-Kani Division (Far North Region, Cameroon)
}

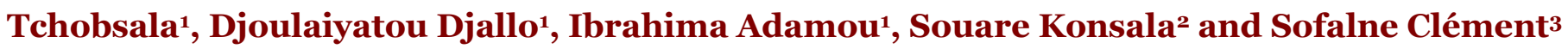 \\ ${ }^{1}$ University of Ngaoundéré, Faculty of Science, Department of Biological Sciences, PO Box: 454, Ngaoundere, Cameroon \\ ${ }^{2}$ University of Maroua, Faculty of Science, Department of Biological Sciences, PO Box: 814, Maroua, Cameroon \\ ${ }_{3}^{3}$ General Director of ABIOGeT (Actions Pour la Biodiversité et Gestion des Terroirs), Canada \\ *Corresponding author.
}

\begin{abstract}
A b stract
The present survey was carried out in the Mayo-Kani Division. It aimed to bring out the present state, the ecological characterization and the sustainable methods of overexploited savannas, gallery forests, afforestated and sacred savannas. Structured and semi structured interviews were realized with 140 people, including the local populations and the authorities within the Delegation of Forests and Fauna, the Delegation of Environment and Protection of Nature, and the council authorities of the Mayo-Kani Division. The inventory of the vegetation was performed on the placettes of $20 \mathrm{~m}$ of radius for the trees and $5 \mathrm{~m}$ of radius for the bushes. The analysis of the data with the help of the software Excel, STATGRAPHICS Plus 5.0 and XLSTAT showed that the overexploited savannas and the gallery forests are highly threatened with a very alarming regression rate because of anthropical activities. The persons responsible for these primordial threats are the agriculturists $(96 \%)$ and the exploiters of nontimber forest products $(89 \%)$. The component principal analysis shows that the species have a sparse distribution on the exploited savannas and the forest galleries. The species such as Parkia biglobosa and Khaya senegalensis present serious threats in the overexploited savannas $(17.02 \mathrm{~kg} / \mathrm{ha})$ and the forest galleries $(23.49 \mathrm{~kg} / \mathrm{ha})$. The measures of co-management and the REDD+ mechanism are taken into account for the management of these four plant formations in the Mayo-Kani Division.
\end{abstract}

\section{Article Info}

Accepted: 29 August 2016

Available Online: 06 September 2016

\section{Ke y w o r d s}

Biodiversity

Ecological characterization

Mayo-Kani Division

Sustainable management

\section{Introduction}

The Central Africa with the signing of the treaty of forest Commission (COMIFAC) and the adoption of the sub regional Convergence Plan in 2005 in Brazzaville, the heads of states and Government of the countries of the Congo Basin confirmed their engagement on principles of biodiversity conservation and the sustainable management of the forest ecosystems. They recognized the rights of their peoples counting on forest resources to sustain their efforts in economic and social development, as well as their adherence with the necessity to reconcile the imperatives of development with the requirements of the conservation in the setting of a sub regional and international coorperation. In general, Africa abounds about 520 millions hectares of the world forests, constituting a real reserve of biodiversity (FAO, 1997). In this part of the terrestrial globe, more than 800 millions of inhabitants live, with the majority being the poor, and depend on these forests for their food, their health, their habitats, as well as their financial incomes. The demographic explosion reported in recent decades has 
adverse effects on the environment because of the unsustainable management of the available natural resources (Palmberg-Lerche, 1997; Antonio, 2002). The demand has become therefore superior to supply because of the demographic growth (Hien et al., 1994; Diop, 2000). Faced with this demand, more than 800 millions people of which 180 millions are found in the less developed countries suffer from famine and malnutrition (Diop, 2000). To alleviate this situation the REDD+ component comes like a means to keep the tropical forests rich in biodiversity and to generate a new flux of incomes in these regions in order to improve the conditions of the poor populations living in agricultural zones (Carmenza et al., 2010).

The 1994 law structuring forest regimes, fauna and fishing dedicates a political and strategic setting to the Cameroonians for the sustainable management of the forests, the contribution to the economic growth, the participatory management and the backing of the public sector on the essential functions.

The Far North Region of Cameroon is an example of region of dry savanna in the central Africa that is confronted with the challenges of demographic explosion (Fotsing, 2009). The increase in population causes a lot of pressures on the natural resources having as aim to satisfy the social and economic needs. We come across a shift in the wooded surfaces in the past 20 years from $29.39 \%$ of soil occupation to $18.45 \%$ throughout the city of Maroua. This reduction first of all attributed to the overexploitation of the woody species to satisfy the growing needs of the populations following a demographic explosion that moved from 1855678 inhabitants in 1998 to 3111792 inhabitants in Far North Region at the time of the third census in 2005 (MINADT, 2010), followed by the conquest of cultivable and arable species. Through this practice was born the concept of change in the use of soils that nowadays is at the origin of the disappearance of the numerous plant formations to the profit of agriculture whose approximate value is estimated at $60 \%$ year (FAO, 1997). Plant formations as well as sacred forests, the afforested savannas, the overexploited savannas, the gallery forests, are not saved from these strategies of sustainable management of the forests. The priority factors of this bad management is deforestation that is an alarming problem in the Mayo-Kani Division where a research study has been carried out because of the overpopulation that exerts a strong pressure on the natural resources. With these conditions, the potential population growth doesn't benefit anymore from forest goods (Hien et al., 1994; FAO, 2002). This situation coupled with climate change of the recent decades has worsened more and has provoked an extreme poverty within the rural population (FAO, 2002). It is therefore these natural and anthropic factors that cause a great problem of soil degradation and even an inadequate system for the sustainable management of natural resources in this zone.

Studies were carried out by Ndam (1998), Doncfack (1998) and Ntoupka (1998) in the soudano-sahelian zone of Cameroon on the dynamics of natural regeneration of vegetation but no work has been done on the state, the characterization and strategies of sustainable management of plant formations in the Kaélé zone which is in an alarming deterioration state and lack of an adequate plan for this management. For that reason, the present work aims to evaluate the state of vegetation, to characterize the typology of the different plant formations, to evaluate the methods of management and conservation of biodiversity in the Mayo-Kani Division.

\section{Materials and methods}

\section{Presentation of the study zone}

The study took place in the Kaélé zone. This zone covers a surface area of about $2000 \mathrm{~km}^{2}$. Situated between $10^{\circ} 02^{\prime}, 10^{\circ} 23^{\prime} \mathrm{N}$ of the latitude and $14^{\circ} 03^{\prime}, 14^{\circ} 42^{\prime}$ of the longitude, the Kaélé plain is limited to the South by the locality of Binder (Tchado-Cameroonian border), to the southwest by the Figuil Subdivision, to the North by the Mindif Subdivision, to the west by the Moutourwa Subdivision and to the East by the Guidiguis Subdivision. To the west, it essentially takes into account the canton of Lara.

The soils of Kaélé as well as those of the Far North are ferruginous and ferralitic resulting to the intensity of leaching affecting this zone. This zone is connected to the sahelian climate with sub-desertic shades. A Sudanosahelian climate reigns in the plain area (with five months of rains, May to October). During this season, vegetation is green (Aaron et al., 2007; Fotsing, 2009). This zone presents an ecological fragility, an increase in aridification of the area and an increase in mortality of the woody species dragging a reduction of biodiversity (Moneze, 1990; Lienou et al., 2003). This zone presents an annual rainfall favorable to the cultivation of cotton and cereals. The zone of study presents a hydrographic network that is more constituted of named temporary flowing river "mayo" that is observed during the rainy season. During the dry season, one only meets vast extended sand on the bed of mayo. 


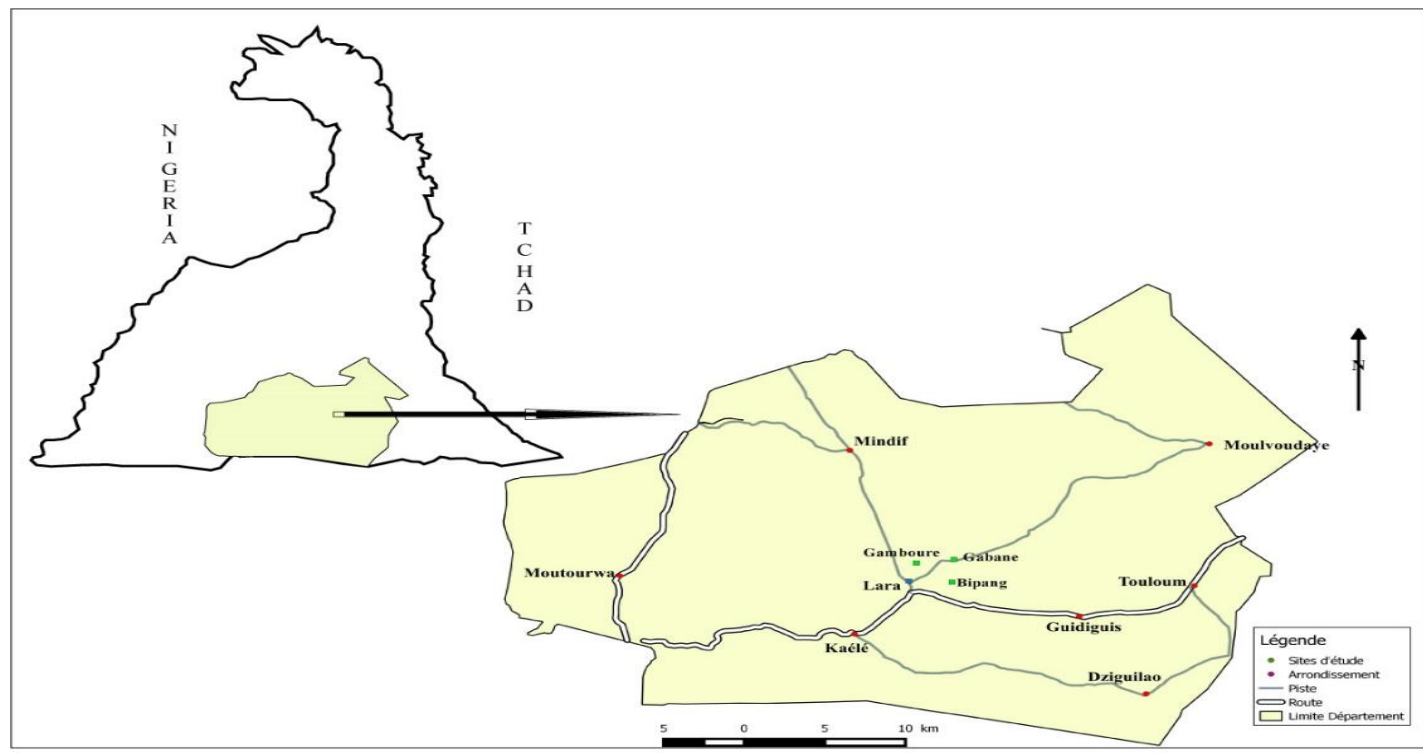

Fig. 1: The map of the study zone.

\section{Methods of data collection}

The study took place in two phases; the first phase concerns the socio-economic investigation, which consisted of interview with semi structured and structured questionnaires, in the households, as well as with the administrative and local authorities. The second consisted of carrying out floristic inventories on the field.

\section{Socio-economic investigation}

This investigation took place in three villages (Bipaing, Gabane and Gaboure) and their surroundings, green-sahel sites, with the local populations, administrative and local authorities. The semi structured and structured questions were administered to 140 people (120 people chosen among the local populations and 20 administrative local authorities). The questionnaires used were divided in the following manner: closed questions (with yes or no response), open questions (of which answers are given deliberately according to one's point of view), oriented questions (which consists of proposing some answers to the respondents) The big categories of the questionnaires were about the state and the strategy of managing plant resources, the causes and the consequences of exploitation of these resources. These investigations were achieved with the help of questionnaires previously established in investigation forms.

\section{Floristic list of the different plant formations}

The choice of the plot is generally oriented and takes into account the adequate measurements of the different plant formations to contain a sample of representative species of the plant community, the uniformity of plant formation excluding all buffer zones, and the heterogeneity of the vegetation of the area considered and that of access paths. The plot method being circular (Fig. 2) was used to collect the data on the woody species. It consists of delimiting with the help of a decameter ribbon, a circle of $20 \mathrm{~m}$ inside which an inventory of vegetation was achieved for the woody circumference greater than or equal to $10 \mathrm{~cm}$ and another circle of $5 \mathrm{~m}$ of radius in regeneration setting. The experimental device is therefore splited to four (4) factors (plant formations), three (3) treatments (plots) and three (3) repetitions (villages).

In every village, 12 plots of $20 \mathrm{~m}$ of radius have been delimited and marked out with the help of the pegs, being a total of 36 plots for the three villages. On every plot, the woody with circumference greater than or equal to $10 \mathrm{~cm}$ and those with circumference $<10 \mathrm{~cm}$ have been inventoried. The dendrometric parameters retained are the diameter at breast height (DBH), the height of the houppier for the woody circumference greater than or equal to $10 \mathrm{~cm}$; the number of stems for the woody circumference $<10 \mathrm{~cm}$ in the circle of $5 \mathrm{~m}$ of radius found in the first.

To evaluate the indicators of the sanitary state of vegetation (mortality, graze, twisted, burnt, natural cut etc.), the method developed by Ouédraogo et al. (2003) has been used. This method consists of observing and counting the number of stems of the sick, dead and living individuals on one plot. 


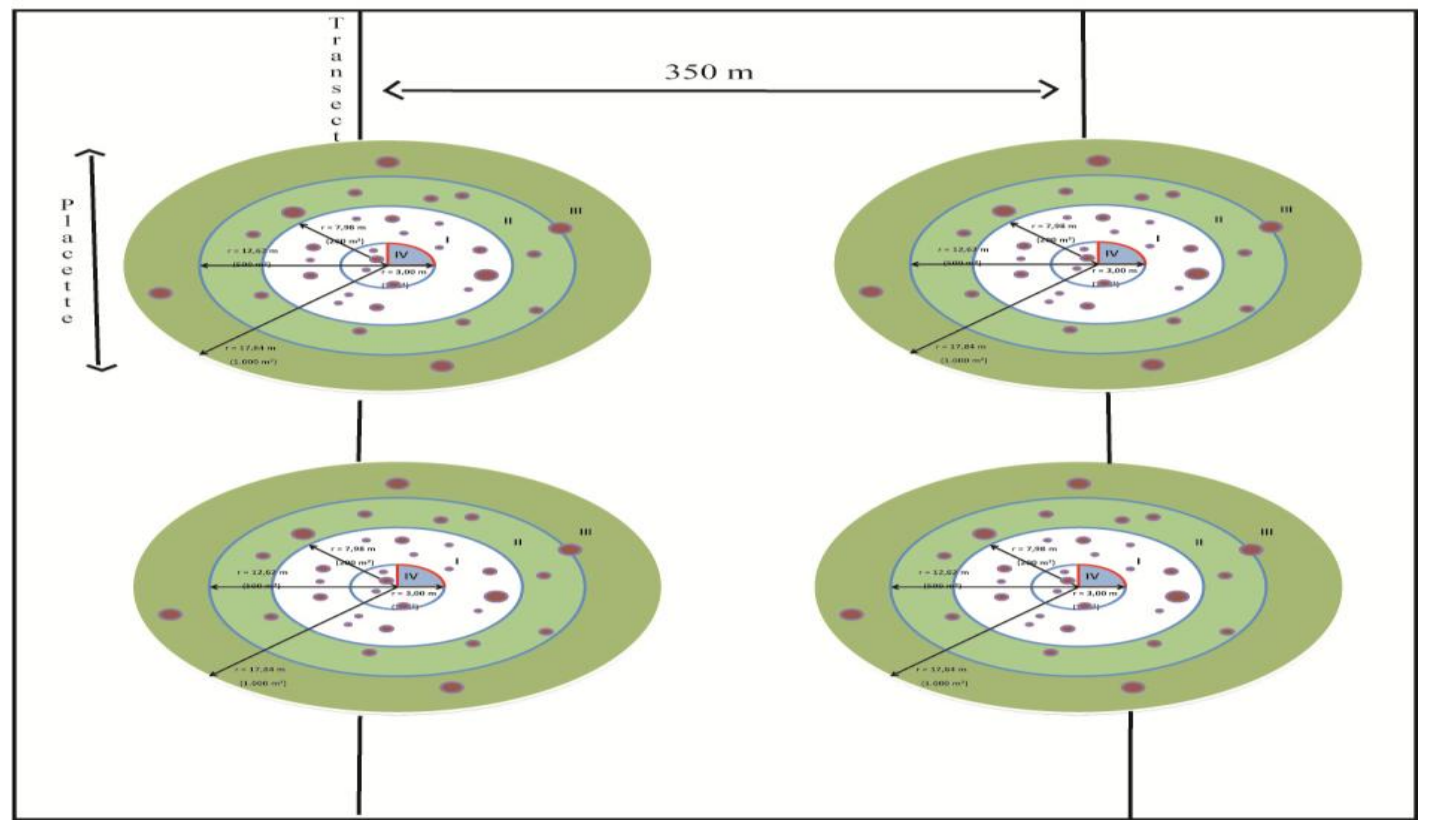

Fig. 2: Experimental device of vegetation inventory.

\section{Data analysis methods}

\section{Frequency of the woody species}

The absolute frequency of the species is the number of the summaries containing this species. According to Braun - Blanquet (1932), the relative frequency is the proportion expressed in percentage between the number of the summaries containing that species and the total number of summaries by 100 . This method permits to determine the accidental species, minor, frequent enough, frequent and very frequent (Table 1).

Table 1. Index of frequency (Braun-Blanquet 1932).

\begin{tabular}{lll}
\hline Index & Frequency & Type of species \\
\hline I & F $<20$ & Accidental species \\
II & $20<\mathrm{F}<40$ & Minor species \\
III & $40<\mathrm{F}<60$ & Frequent enough species \\
IV & $60<\mathrm{F}<80$ & Frequent species \\
V & $80<$ F. 100 & Very frequent species \\
\hline
\end{tabular}

\section{Similarity coefficient of Jaccard}

The similarity coefficient of Jaccard (Floch, 2007) permits to compare the different plots. It is given by the formula:

$$
\mathbf{P J}=\frac{c}{a+b-c} \times \mathbf{1 0 0}
$$

Where,

$\mathrm{a}=$ number of species of the area $1, \mathrm{~b}=$ number of species of the area 2, c = number of species common to the two surroundings or areas.
The similarity between habitats is expressed by the highest value of this indication. The distance of Hamming proposed by Daget and Poissonnet (1971) is added to this indication to compare the floristic summaries according to the formula:

Where,

$$
\mathbf{H}=\mathbf{1 0 0}-\mathbf{P J}
$$

PJ is the indication of Jaccard. Doorsteps are resumed in Table 2.

Table 2. Doorstep of comparison of the floristic summaries according to the distance of Hamming.

\begin{tabular}{ll}
\hline Doorstep & Comparison \\
\hline H. 20 & Very weak floristic difference \\
$20<\mathrm{H} .40$ & Weak floristic difference \\
$40<\mathrm{H} .60$ & Middle floristic difference \\
$60<\mathrm{H} .80$ & Strong floristic difference \\
$80<\mathrm{h}$ & Very strong floristic difference \\
\hline
\end{tabular}

\section{Relative density}

The relative density (RD) or relative abundance is the report between the number of individuals of a species and the total number of all individuals of species encountered on a considered surface multiplied by 100 .

\section{Relative absolute dominance}

The dominance expresses the influence exercised by a species in a community. The relative dominance (RD) is 
the report of the basal area $(\mathrm{Sb})$ of a species on the total basal area of all individuals encountered. $\mathrm{Sb}=\pi \mathrm{D}^{2} / 4$. $\mathrm{D}$ : being the diameter of the stem.

\section{Curtis value importance}

The three statistical data (frequency, dominance and relative density) are commonly used together and their sum is equal to the "Curtis Value Importance."

\section{Indications of floristic diversity}

The diversity indication of Shannon:

$$
\mathrm{ISH}=-\Sigma \mathrm{Ni} / \mathrm{N} \log _{2}(\mathrm{Ni} / \mathrm{N})
$$

Where,

$\mathrm{Ni}$ is the effectiveness of the species; the Equitability (EQ) of Piélou (1966): EQ = ISH/log2N.

\section{Basal area}

It is given by the formula:

$$
\mathrm{Gi}=\pi \mathrm{D}^{2} / 4
$$

Where,

Gi is the basal area of the species i, D is the diameter of the bunch of species.

\section{Techniques of data analysis}

The variance analysis (ANOVA) has been achieved with the help of the software stratgraphic.5. The parameters whose analysis proved to be meaningful have been kept for the development of the Principal Component Analysis (PCA) and the Hierarchical Ascending Classification (HAC) with the help of the software XLSTAT.

\section{Results}

\section{State of deterioration of the different plant formations in the of Mayo-Kani Division}

Fig. 3 shows that overexploited savanna (57\%) and the gallery forest $(52 \%)$ are in perpetual deteriorations according to the answers from the local population. The afforested savanna (22\%) and the sacred forest (9\%) have a very weak percentage of deterioration because of the weak anthropical pressure on the plant resources. These two zones are protected on the one hand by the government and on the other hand by the native population. In a general manner the sacred forests in the Mayo-Kani Division are forbidden positively from exploitation, even from cutting of wood for domestic energy. It is a place where only the insiders can surrender of it during the period of initiation. The chiefs are rigorous to maintain this tradition. In the same way the exploitation of the afforested forests is forbidden by the forest law. The follow-up agents and control of this plant formation ensure the application of existing texts. It is for this reason that the sacred forests and the afforested forests have less anthropical pressure and the deterioration of these two formations is weak.

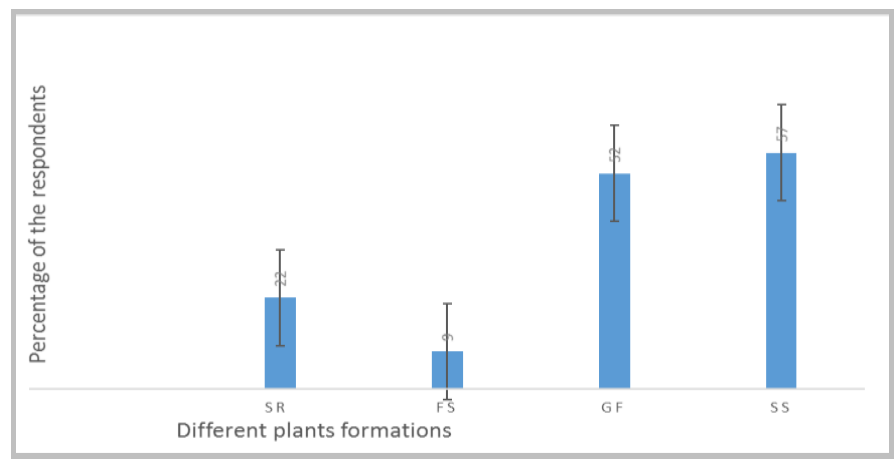

Fig. 3: The state of vegetation. SR= Afforestated savanna; FS= Sacred forest; $\mathrm{GF}=$ gallery forest; $\mathrm{SS}=$ Overexploited savanna.

\section{Indices of anthropisation of the natural formations}

The index of anthropisation is very important in the overexploited savannas and the gallery forests that nearly represent $60 \%$ of traces of pruning and the cuts of wood (Fig. 4). In these formations all sampled plots presented traces of cuts and pruning. These strong anthropic pressures in these two formations are justified by the free access of the indigenous residents in these formations and the strong demand for natural resources. In the overexploited savannas the indigenous population derives the essential wood and non woody forest products, wood energy to satisfy their needs without any constraint. Equally, in gallery forests, the population practices the crops against season, vegetables and the agrosylvopastoral practices without any almond.

\section{Actors of natural resource exploitation}

The main actors involved in natural resource exploitation are farmers $(96 \%)$ because they practise burn agriculture in their exploitation system, followed by collectors of non timber forest products $(89 \%)$ who collect service woods, fruits, leaves, barks, roots and craftsmen (81.5\%) who use these resources for the construction of the 
habitats, stains and other traditional products and finally the breeders $(52.5 \%)$ who graze their animals in vegetation (Fig. 5). The other groups concern the fishermen $(38.33 \%)$, the hunters $(31.66 \%)$ and the blacksmiths (10\%) who intervene weakly in the exploitation of the forest resources in this zone.

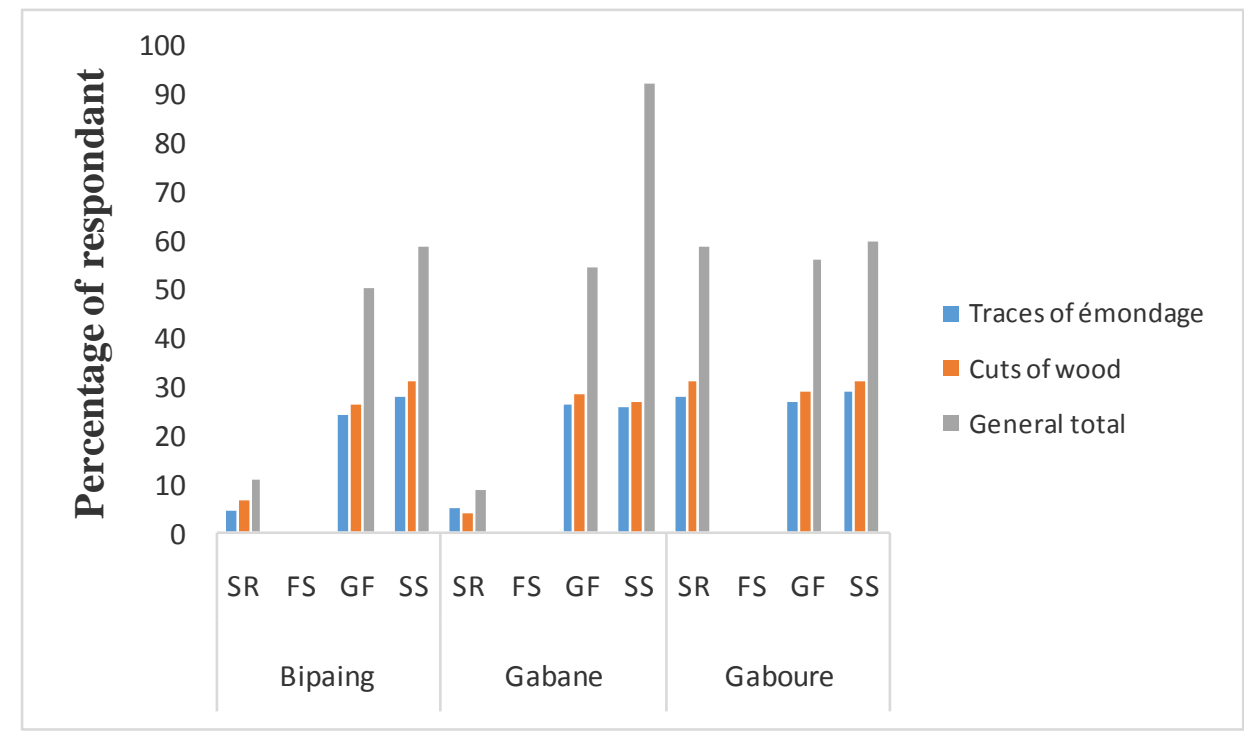

Fig. 4: Indices of anthropisation on natural resources. $\mathrm{SR}=$ Afforestated savanna, FS= Sacred forest, $\mathrm{GF}=$ gallery forest, $\mathrm{SS}=$ Overexploited savanna.

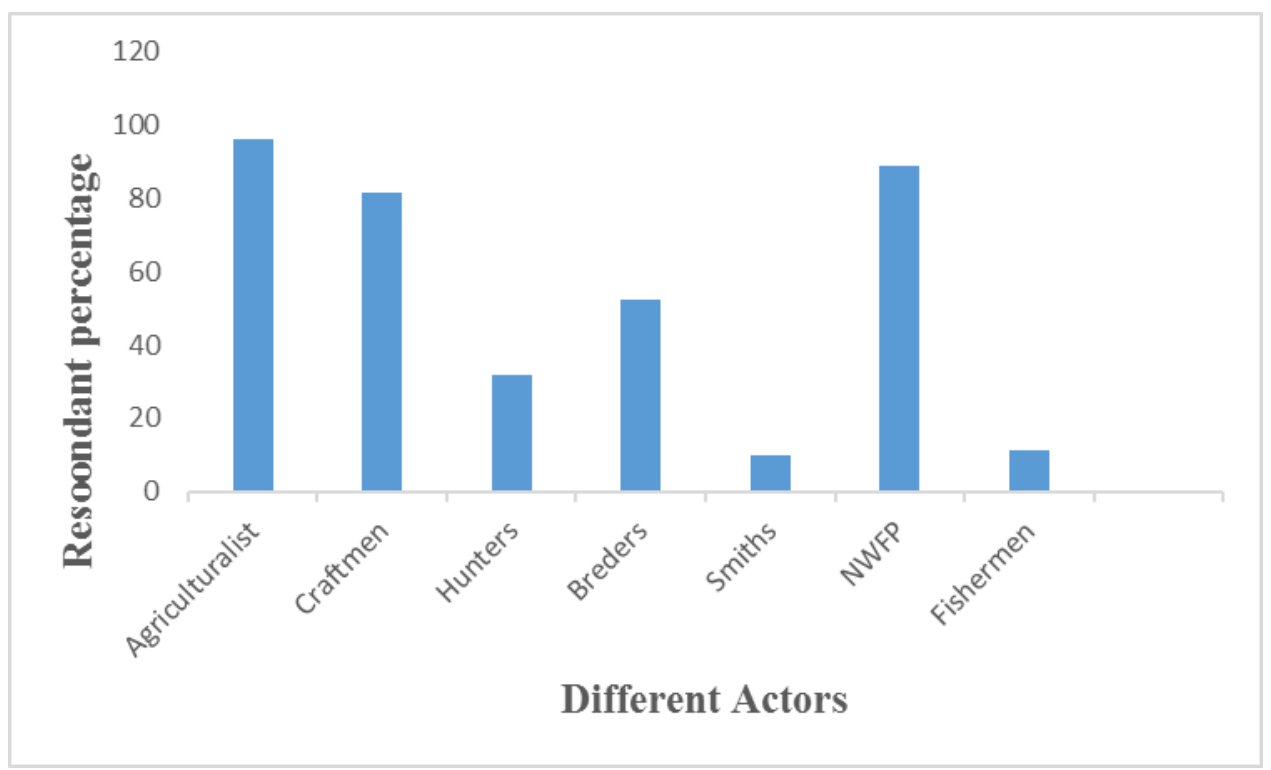

Fig. 5: Collectors of natural resources.

\section{Reasons for the exploitation of natural resources in the Mayo-Kani Division}

The agricultural practice $(95.66 \%)$ and the search for financial means $(52.33 \%)$ present significant differences $(0.033<0.05)$ and therefore represent the main causes of natural resource exploitation (Table 3).

All the three villages practise agriculture (100\%).
Priority species mostly used by the local population in the Mayo-Kani Division

The plant species mostly exploited in the study zone have been listed following their multiple uses. Balanites aegyptiaca $(99.11 \%)$ is used for all services (service wood, fire-chamber wood for feeding traditional handicraft, pharmacopeia, fodder for animals) followed by Khaya senegalensis (98.26\%) 
and Parkia biglobosa $(95.43 \%)$ that are also mostly solicited in the three villages like wood of work, handicraft, service wood, fodder, traditional pharmacopeia and food (Table 4).

Table 3. Reasons for the exploitation of natural resources in the Mayo-Kani Division.

\begin{tabular}{lllll}
\hline Reasons & Bipaing & Gabane & Gaboure & Average \\
\hline Burn agriculture & 94 & 96 & 97 & $95.66 \pm 1.24 \mathrm{~b}$ \\
Search for financial means & 44 & 49 & 64 & $52.33 \pm 8.49 \mathrm{~b}$ \\
Needs for domestic energy & 45 & 35 & 35 & $38.33 \pm 4.71 \mathrm{~b}$ \\
Search for jobs & 35 & 24 & 30 & $29.67 \pm 4.50 \mathrm{~b}$ \\
Affectation of civil servants & 35 & 27.5 & 15 & $25.83 \pm 8.25 \mathrm{~b}$ \\
Others & 25 & 22.5 & 10 & $19.17 \pm 6.56 \mathrm{c}$ \\
Transhumance & 21 & 21.5 & 12 & $18.17 \pm 6.56 \mathrm{c}$ \\
\hline
\end{tabular}

The figures affected by the same letters are not significant to the doorstep of 5\%.

Table 4. Plant species mostly used in the Mayo-Kani Division (\%).

\begin{tabular}{llllllll}
\hline Species & Fe & Fc & Tp & Fo & Cw & Sw & General total \\
\hline Balanites aegyptiaca & 44 & 19.33 & 19 & 7.66 & 4.01 & 5 & 99.11 \\
Khaya senegalensis & 0 & 7.26 & 49 & 0 & 24 & 18 & 98.26 \\
Parkia biglobosa & 52.33 & 8.78 & 9.99 & 8 & 7.33 & 9 & 95.43 \\
Anogeissus leiocarpus & 0 & 47 & 20 & 14 & 0 & 13 & 94 \\
Sclerocarya birrea & 14.15 & 18 & 0 & 11.11 & 38.2 & 12.23 & 93.69 \\
Piliostigma thonningii & 2.88 & 31.14 & 20 & 18 & 11 & 9 & 92.02 \\
Vittalaria paradoxa & 20.44 & 14 & 34 & 2 & 4 & 8 & 82.44 \\
Stereospermum kunthianum & 0 & 6 & 7 & 33 & 0 & 2 & 48 \\
Boswellia dalzielii & 0 & 11 & 6.66 & 0.00 & 30 & 0 & 47.66 \\
Acacia albida & 0 & 2.33 & 9 & 36 & 0 & 0 & 47.33 \\
\hline
\end{tabular}

$\mathrm{Bs}=$ service wood, $\mathrm{Fc}=$ fire-chamber wood, $\mathrm{Tp}=$ traditional pharmacopeia, $\mathrm{Fe}=$ food, $\mathrm{Fo}=$ fodder, $\mathrm{Cw}=\mathrm{craftwork}$

\section{Socio environmental impact of natural resource} exploitation

The bad exploitation of natural resources principally causes the disappearance of biodiversity $(87 \pm 3.60 \%)$, the increase of poverty $(92 \pm 3.60 \%)$, the climatic change $(58 \pm 7.21 \%)$ and soil erosion $(53.33 \pm 10.06 \%)$ in the three villages according to the respondents (Table 5).

Table 5. Socio environmental impacts of natural resource exploitation (\%).

\begin{tabular}{lllll}
\hline Elements & Bipaing & Gabane & Gaboure & Average \\
\hline Increase in poverty & 89 & 91 & 96 & $92 \pm 3.60$ \\
Rare precipitation & 86 & 87 & 91 & $88 \pm 2.64$ \\
Biodiversity & 84 & 86 & 91 & $87 \pm 3.60$ \\
disappearance & & & & \\
Climatic change & 56 & 66 & 63 & $58 \pm 7.21$ \\
Soil erosion & 64 & 44 & 52 & $53.33 \pm 10.06$ \\
\hline
\end{tabular}

\section{Progressive disappearance of the species in the three} villages

A total of 17 species has been mentioned by the peasants. These species are strongly threatened with the disappearance of some species among them such as Khaya senegalensis, Parkia biglobosa (Fig. 6). This disappearance is due to the fact that these species are solicited very much by the population of this study zone. This observed variability is statistically very meaningful $(0.00<005)$. Whereas, between the villages a meaningful difference doesn't exist.

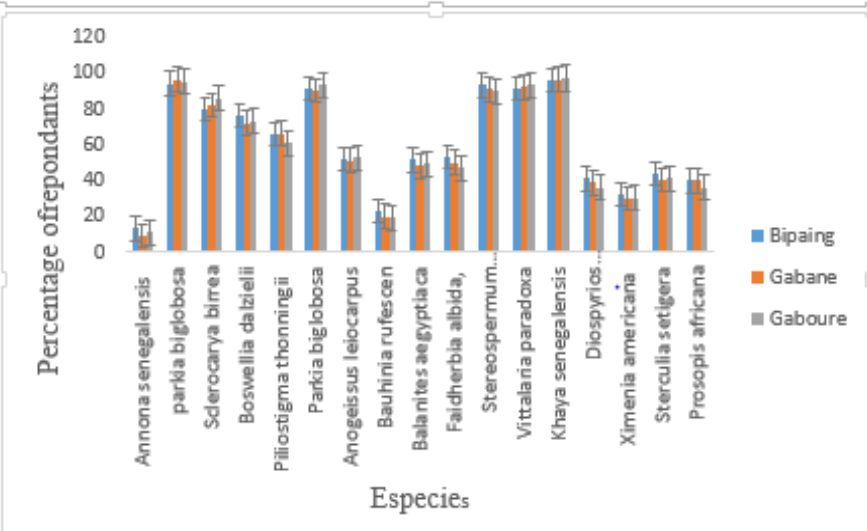

Fig. 6: Species disappearance in the three villages.

\section{Different ways of disappearance of species in plant formation}

The way of disappearance of vegetation species sums up to the actions of man. It is mainly about cutting and others that are the most practised by the individuals 
(Fig. 7). They are mostly practised in overexploited savannas and gallery forests. The cutting is destined for domestic energy and the raw material for the handicraft and the traditional medicine.

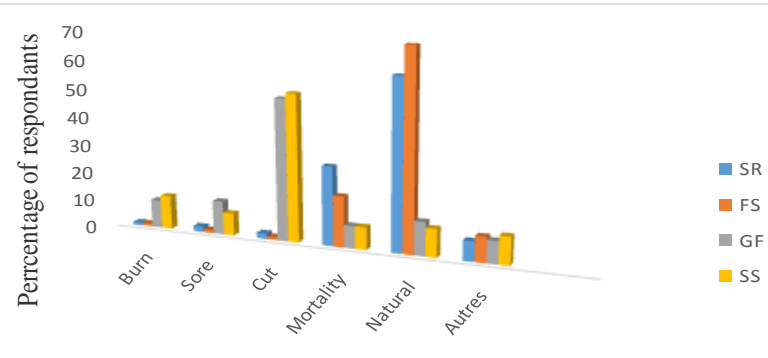

Disappearance fashions

Fig. 7: Impact of the exploitation of the natural resources on the health of the individuals ( $\mathrm{SR}=$ Afforestated savanna, FS= Sacred forest, $\mathrm{GF}=$ gallery forest, $\mathrm{SS}=$ Overexploited savanna).

\section{Influence of exploitation of plant formations on floristic diversity}

The inventories achieved on the different plant formations permit to count 1768 individuals/ha of woody divided into 82 species, 59 genera and 26 families (table 6). The overexploited (542 individuals/ha) savannas have the richest formation in terms of density because of the repeated cuts of this formation, and that favours the fast regeneration of the species. Species such as Piliostigma reticulatum and Combretum adenogonium have strong densities of regeneration after wood cut. But this increase in the number of stems is not synonymous to a great diversity of species, genera and family in the different plant formations. Table 6 shows that the overexploited savanna has the weak number of species (24), in genera (20) and family (9) in relation to the afforested savanna and sacred forest. They have 62 and 54 respectively for the number of species, 48 and 43 for the genera and finally 21 and 18 for the number of family. In effect, when a plant formation is protected, there is recruitment of new species. It is for this reason that the number of species, genera and family increased in the afforested savannas and the sacred forests.

Table 6. Density and floristic diversity of vegetation in formation function.

\begin{tabular}{llllll}
\hline & SR & FS & GF & SS & Total \\
\hline Individuals & 445 & 347 & 434 & 542 & 1768 \\
Species & 62 & 54 & 28 & 24 & 168 \\
Gender & 48 & 43 & 22 & 20 & 133 \\
Families & 21 & 18 & 11 & 9 & 59 \\
\hline
\end{tabular}

$\mathrm{SR}=$ Afforestated savanna, $\mathrm{FS}=$ Sacred forest, $\mathrm{GF}=$ gallery forest, $\mathrm{SS}=$ Overexploited savanna

\section{Ecological characteristics of plant species in the Mayo-Kani Division}

The frequency, density and relative abundance permit to know the ecological importance of the species in plant formations in the Mayo-Kani Division. Table 7 shows that 5 species have an importance value of Curtis and are more than 10. They are Combretum adenogonium (49.87\%), Balanites aegyptiaca (32.03\%), Cassia singueana (17.25\%), Cassia sieberiana (14.49\%), Combretum nigricans (12.22\%). These species have characteristics of the sahelian zone and adapt very easily to arid zones.

Table 7. Frequency, Density, Dominance, Importance value of Curtis and Number of individual species; RF Relative Frequency, ReD =Relative Density, ReD =Relative Dominance, IRVC = Importance Relative Value of Curtis.

\begin{tabular}{llllllllll}
\hline Species & FR & DeR & DR & IVCR & Species & FR & DeR & DR & IVCR \\
\hline Acacia albida & 0.19 & 0.2 & 035 & 0.74 & Entada africana & 1.52 & 0.33 & 0.63 & 2.48 \\
Acacia ataxacantha & 0.51 & 0.15 & 0.29 & 0.95 & Faidherbia albida & 1.33 & 0.25 & 0.76 & 2.34 \\
Acacia gerrardii & 1.7 & 0.85 & 0.48 & 3.03 & Feretia apodenthera & 2.84 & 0.24 & 2.13 & 5.21 \\
Acacia hockii & 0.04 & 0.13 & 0.55 & 0.72 & Ficus gnapholocarpa & 1.33 & 0.32 & 0.48 & 2.13 \\
Acacia nilotica & 0.19 & 0 & 0.13 & 0.32 & Ficus iteophylla & 1.52 & 1.64 & 1.37 & 4.53 \\
Acacia polyancantha & 0.95 & 1.06 & 0.69 & 2.7 & Ficus spp. & 1.52 & 0.87 & 1.1 & 3.49 \\
Acacia senegal & 0.38 & 0.01 & 0.13 & 0.52 & Ficus sycomorus & 0.19 & 0 & 0 & 0.19 \\
Acacia seyal & 0.19 & 0 & 0 & 0.19 & Ficus thoningii & 1.04 & 0 & 0 & 1.04 \\
Acacia sieberiana & 1.52 & 3.21 & 2.54 & 7.27 & Gardenia erubescens & 1.42 & 0.47 & 0.45 & 2.34 \\
Acacia tortillis & 0.38 & 0.18 & 0.13 & 0.69 & Gardenia ternifolia & 1.52 & 1.64 & 1.37 & 4.53 \\
Adansonia digitata & 0.19 & 0.03 & 0.07 & 0.29 & Grewia barteri & 0.38 & 0.17 & 0.13 & 0.68 \\
Afzelia africana & 0.38 & 1.17 & 1.52 & 3.07 & Grewia bicolor & 0 & 0.39 & 0.14 & 0.53 \\
Albizia chevalieri & 2.84 & 2.38 & 1.65 & 6.87 & Grewia cissoides & 0.38 & 0.17 & 0.13 & 0.68 \\
Andira inermis & 2.08 & 0.09 & 1.04 & 3.21 & Grewia flavescens & 0.19 & 0.01 & 0.07 & 0.27 \\
Annona senegalensis & 2.08 & 0.27 & 1.3 & 3.65 & Guiera senegalensis & 0.95 & 0.16 & 0.41 & 1.52 \\
Anogeissus leocarpa & 2.65 & 3.99 & 2.95 & 9.59 & Hexalobus monopetalus & 1.52 & 0.33 & 0.63 & 2.48 \\
\hline
\end{tabular}




\begin{tabular}{|c|c|c|c|c|c|c|c|c|c|}
\hline Species & FR & DeR & DR & IVCR & Species & FR & DeR & DR & IVCR \\
\hline Azadirachta indica & 1.3 & 1.2 & 1.45 & 3.95 & Hyphaene thebaica & 1.08 & 0.9 & 1.04 & 3.02 \\
\hline Balanites aegyptiaca & 3.22 & 20.6 & 8.17 & 32.03 & Kaya senegalensis & 0.57 & 0.26 & 0.41 & 1.24 \\
\hline Bombax costatum & 3.41 & 2.49 & 3.84 & 9.74 & Maerua crassifolia & 0.19 & 0.02 & 0.07 & 0.28 \\
\hline Boscia senegalensis & 0.76 & 0.04 & 0.28 & 1.08 & Maytenus senegalensis & 2.08 & 0 & 0 & 2.08 \\
\hline Bridelia tenuifolia & 1.89 & 0.25 & 1.24 & 3.38 & Mitragina inermis & 1.04 & 0.91 & 1.52 & 3.47 \\
\hline Boscia senegalensis & 2.08 & 0.71 & 1.6 & 4.39 & Piliostigma reticulatum & 1.14 & 0.24 & 0.41 & 1.79 \\
\hline Boswellia dalziellii & 0.95 & 0.18 & 0.69 & 1.82 & Piliostigma thoningii & 2.08 & 0.18 & 1.1 & 3.36 \\
\hline Burkea africana & 0.38 & 0.01 & 0.21 & 0.6 & Prosopis african & 0.47 & 0.23 & 0.14 & 0.84 \\
\hline Capparis corymbosa & 2.08 & 0.21 & 1.1 & 3.39 & Pterocarpus erinaces & 1.14 & 0.65 & 1.37 & 3.16 \\
\hline Capparis sepiaria & 0.57 & 0.12 & 0.41 & 1.1 & Salvadora percica & 0.65 & 0.39 & 0.41 & 1.45 \\
\hline Cassia siamea & 0.57 & 0.49 & 0.21 & 1.27 & Sarcocephalus latifolus & 0.33 & 0.55 & 0.63 & 1.51 \\
\hline Cassia sieberiana & 3.41 & 3.6 & 7.48 & 14.49 & Sclerocarya birrea & 1.89 & 0.24 & 0.89 & 3.02 \\
\hline Cassia singueana & 2.65 & 5.13 & 9.47 & 17.25 & Senna seamea & 2.65 & 0.15 & 0.96 & 3.76 \\
\hline Celtis integrifolia & 0.76 & 0 & 0 & 0.76 & Senna singueana & 0.19 & 0 & 0 & 0.19 \\
\hline Combretum adenogonium & 3.98 & 29.1 & 16.8 & 49.87 & Sterculia setigera & 0.38 & 0 & 0.07 & 0.45 \\
\hline Combretum collinum & 0.95 & 0.01 & 0.35 & 1.31 & Stereospermum kunthianum & 0.5 & 0.15 & 0.29 & 0.94 \\
\hline Combretum nigricans & 2.98 & 3.61 & 5.63 & 12.22 & Tamarindus indica & 1.52 & 0.52 & 0.41 & 2.45 \\
\hline Combretum glutinosum & 1.89 & 0.73 & 1.04 & 3.66 & Terminalia avicennioides & 3.03 & 0.65 & 1.25 & 4.93 \\
\hline Commiphora africana & 0.19 & 0 & 0 & 0.19 & Terminalia macroptera & 0.21 & 0.32 & 0.21 & 0.74 \\
\hline Crateva adansoni & 1.14 & 0.45 & 0.69 & 2.28 & Terminalia mollis & 0.19 & 0.05 & 0.07 & 0.31 \\
\hline Crateva religiosa & 0.19 & 0 & 0.07 & 0.26 & Vitellaria paradoxa & 0.19 & 0.2 & 0.35 & 0.74 \\
\hline Crossopteryx febrifuga & 0.57 & 0.16 & 0.21 & 0.94 & Vitex doniana & 0.76 & 0 & 0.07 & 0.83 \\
\hline Detarium microcarpum & 1.52 & 0.74 & 0.89 & 3.15 & Ximenia americana & 0.51 & 0.15 & 0.29 & 0.95 \\
\hline Dicrostachys cinera & 0.38 & 0.01 & 0.21 & 0.6 & Ziziphus mauritiana & 2.65 & 1.24 & 1.54 & 5.43 \\
\hline \multirow[t]{2}{*}{ Diospyros mespiliformis } & 2.44 & 1.62 & 1.19 & 5.25 & Ziziphus mисronata & 0.57 & 0 & 0 & 0.57 \\
\hline & & & & & Total & 100 & 100 & 100 & 300 \\
\hline
\end{tabular}

\section{Diversity at the level of families}

Combretaceae (72.69\%), Caesalpiaceae (45.4\%), Balanitaceae (32.22\%), Mimosaceae (22.72\%), Ulmaceae (17.25\%), Burceraceae (16.61\%), Rubiaceae (13.47\%), Moraceae (11.38\%), Bombacaceaes (10.03\%) are families that are ecologically adapted in the department of the
Mayo-Kani. Their importance value of Curtis is superior or equal to 10 (Table 8). However the Olacaceae families $(0.95 \%)$, Bignoniaceae $(0.94 \%)$, Verbenaceae $(0.83 \%)$, Sapotaceae $(0.74$ Tilliaceae $(0.69 \%)$, Sterculiaceae $(0.45 \%)$ have a very weak importance value of curtis in the Division which shows that their capacity of adaptation in this zone is very weak.

Table 8. Importance Value of Curtis of the different families.

\begin{tabular}{llllll}
\hline Families & NI & RF & ReD & RD & IRVC \\
\hline Combretaceae & 481 & 14.61 & 35 & 23.08 & 72.69 \\
Caesalpiaceae & 332 & 19.9 & 9.77 & 15.73 & 45.4 \\
Balanitaceae & 66 & 3.41 & 20.64 & 8.17 & 32.22 \\
Mimosaceae & 117 & 9.56 & 6.41 & 6.75 & 22.72 \\
Ulmaceae & 158 & 2.65 & 5.13 & 9.47 & 17.25 \\
Burseraceae & 106 & 5.06 & 4.32 & 7.23 & 16.61 \\
Rubiaceae & 72 & 6.2 & 2.33 & 4.94 & 13.47 \\
Moraceae & 75 & 5.6 & 2.83 & 2.95 & 11.38 \\
Bombacaceae & 24 & 3.6 & 2.52 & 3.91 & 10.03 \\
Capparaceae & 37 & 3.71 & 0.58 & 2.15 & 6.44 \\
Fabaceae & 37 & 3.22 & 0.74 & 2.41 & 6.37 \\
Annonaceae & 45 & 3.6 & 0.6 & 1.93 & 6.13 \\
Rhamnaceae & 24 & 3.22 & 1.24 & 1.54 & 6.00 \\
Tiliaceae & 26 & 1.9 & 2.2 & 1.64 & 5.74 \\
Ebenaceae & 33 & 2.44 & 1.62 & 1.19 & 5.25 \\
Meliaceae & 30 & 1.87 & 1.46 & 1.86 & 5.19 \\
Euphorbiaceae & 30 & 3.11 & 0.4 & 1.51 & 5.02 \\
Anacardiaceae & 17 & 1.89 & 0.24 & 0.89 & 3.02 \\
\hline
\end{tabular}




\begin{tabular}{llllll}
\hline Families & NI & RF & ReD & RD & IRVC \\
\hline Arecaceae & 20 & 1.08 & 0.9 & 1.04 & 3.02 \\
Salvadoraceae & 6 & 0.65 & 0.39 & 0.41 & 1.45 \\
Olacaceae & 5 & 0.51 & 0.15 & 0.29 & 0.95 \\
Bignoniaceae & 5 & 0.5 & 0.15 & 0.29 & 0.94 \\
Verbenaceae & 9 & 0.76 & 0 & 0.07 & 0.83 \\
Sapotaceae & 8 & 0.19 & 0.2 & 0.35 & 0.74 \\
Tiliaceae & 2 & 0.38 & 0.18 & 0.13 & 0.69 \\
Sterculiaceae & 2 & 0.38 & 0 & 0.07 & 0.45 \\
Total & 1767 & 100 & 100 & 100 & 300 \\
\hline
\end{tabular}

$\mathrm{NI}=$ Number of Individuals, RF Relative Frequency, ReD =Relative Density, ReD =Relative Dominance, IRVC = Importance Relative Value of Curtis

\section{Horizontal structure of the woody in different plant formations}

The species with $\mathrm{DBH} \geq 10 \mathrm{~cm}$ are dominant in sacred forest followed by afforested savanna but weak in the overexploited savanna and the gallery forest while species with $\mathrm{DBH} \geq 5 \mathrm{~cm}$ makes the opposite meaning, they are dominant in the overexploited savanna and the gallery forest but are in a minority in the afforestated savanna and sacred forest. In the whole vegetation, this zone is dominated by the individuals with diameter inferior or equal to $5 \mathrm{~cm}$ (Fig. 8). These results are justified by the fact that the repeated cuts in the overexploited savanna and forest gallery encourage a fast regeneration of the species.

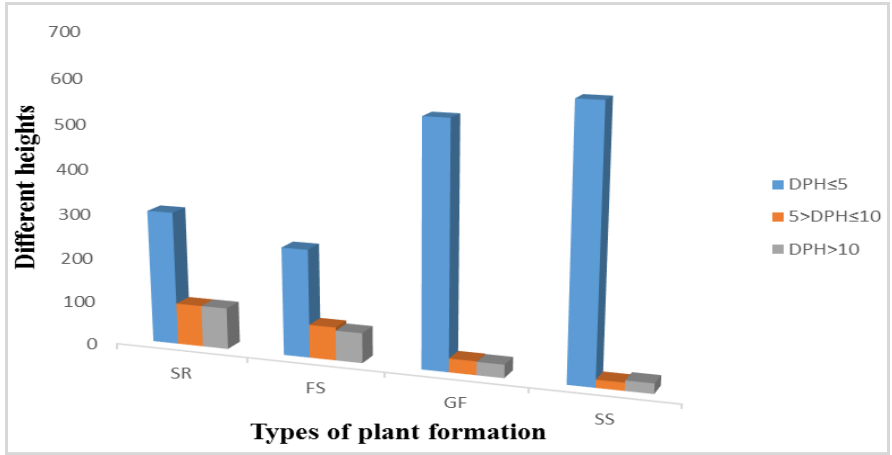

Fig. 8: Distribution of individuals according to the diameters of their bunch. SR= Afforestated savanna, FS= Sacred forest, $\mathrm{GF}=$ gallery forest, $\mathrm{SS}=$ Overexploited savanna .

\section{Vertical structure of different woody plant formation}

The individuals that size is lower than $1.30 \mathrm{~m}$ are abundant in the vegetation. What translates a strong regeneration of the woody in the site. This regeneration is marked by overexploited savanna and the gallery forest respectively (501individuals/ha) and (373 individuals/ha). The woody with superior sizes of $10 \mathrm{~m}$ are less represented in the general site (Fig. 9).

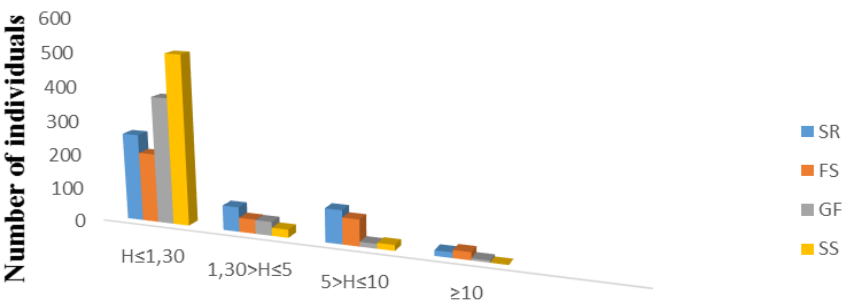

Class Height

Fig. 9: Distribution of species according to their sizes, average and their numbers.

\section{Types of regeneration}

Table 9 presents the types of regeneration of the woody species in the different plant formations. It brings out the fact that the natural regeneration is more important in the plant formations $(38.59 \%)$. They represent $65.68 \%$ of the sacred forests whereas in the afforested savannas, gallery forests, the overexploited savannas, they occupy $14.03 \%$, $13.55 \%$ and $6.11 \%$ respectively.

The analysis of variance at the doorstep of 5\% revealed a non significant difference between the different types of plant formations and between the types of regeneration encountered $(p>0.01)$.

Table 9. Types of regeneration (\%).

\begin{tabular}{lllll}
\hline & SR & FS & GF & SS \\
\hline Natural & 6.11 & 90 & 20 & 23 \\
Artificial & 93.89 & 10 & 80 & 77 \\
\hline
\end{tabular}

$\mathrm{SR}=$ Afforestated savanna, $\mathrm{FS}=$ Sacred forest, $\mathrm{GF}=$ gallery forest, $\mathrm{SS}=$ Overexploited savanna

\section{States of offshoots in the different plant formations}

The overexploited savanna is the plant formation where the number of the individuals at the rejection state is more abundant (501 stems / ha) followed by gallery forest (373 stems/ha). The rejection density is very 
weak in the afforestated savanna (257 stems/ha) savanna and the sacred forest (204 stems/ha) (Fig. 10).

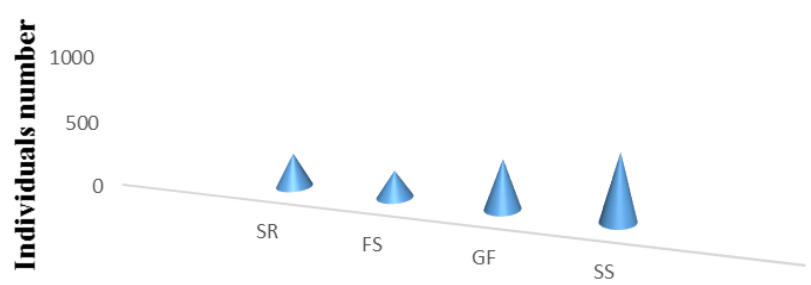

Types of plant formation

Fig. 10: States of offshoots in the plant formations. SR= Afforestated savanna, $\mathrm{FS}=$ Sacred forest, $\mathrm{GF}=$ gallery forest, $\mathrm{SS}=$ Overexploited savanna.

Index of Shannon, Equitability of Pielou in the different plant formations of the Mayo-Kani Division

The Shannon tree index is very high in sacred forest (1.46) and the afforestated savanna (1.57) whereas amongst the bushes it is very high in the overexploited savanna (1.66) and the gallery forest (1.36).That is justified by the fact that in the overexploited savannas and forest galleries where anthropic disturbances are more abundant, number of bushes is high and consequently Shannon index becomes also important. As for the Equitability of Pielou they are proportional to the calculated index of Shannon. The calculated values of the Equitability of Pielou in the different plant formations are weak with the biggest value seen in the afforestated savanna, that's 0.79 for the trees and in the overexploited savanna with a value of 0.70 for the bushes. These weak values (Fig. 11) show that the studied vegetation is weak in biodiversity.

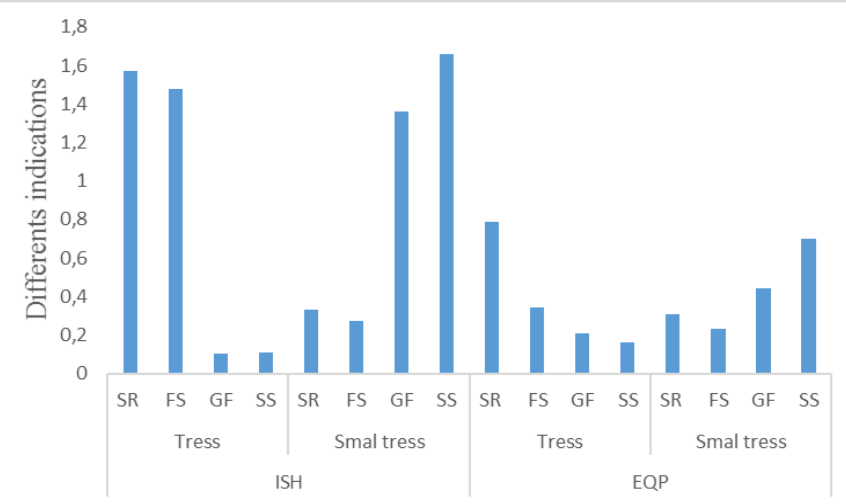

Fig. 11: Index of Shannon, Equitability of Pielou. SR= Afforestated savanna, FS= Sacred forest, GF= gallery forest, $\mathrm{SS}=$ Overexploited savanna.

\section{Species dispersal according to the dendrometric parameters}

The principal component analysis of the species showed the respective percentages $(\mathrm{F} 1=53.19 \%$, $\mathrm{F} 2=30.79 \%, \mathrm{~F} 1+\mathrm{F} 2=83.98 \%$ ). One observes a close relation between the number of individuals and the size of the trees which means that a very important positive interrelationship exists between the number of individuals or density and size. This is justified by the fact that the size of every individual encountered in the site was estimated, that's not the case of the diameter at breast height. Concerning the species, they are grouped into origin and form a cloud of the points (Fig. 12). That shows that the vegetation is constituted mostly of accidental species. It can be equally observed a very baffled distribution of Anogeissus leiocarpus and Combretum adenogosum that will be justified by their abundance and their elevated diversity in the sites.

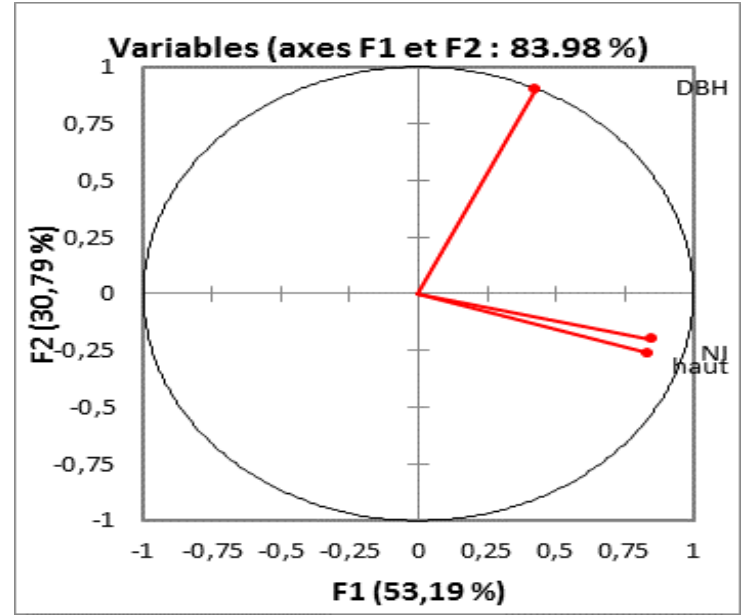

(a)

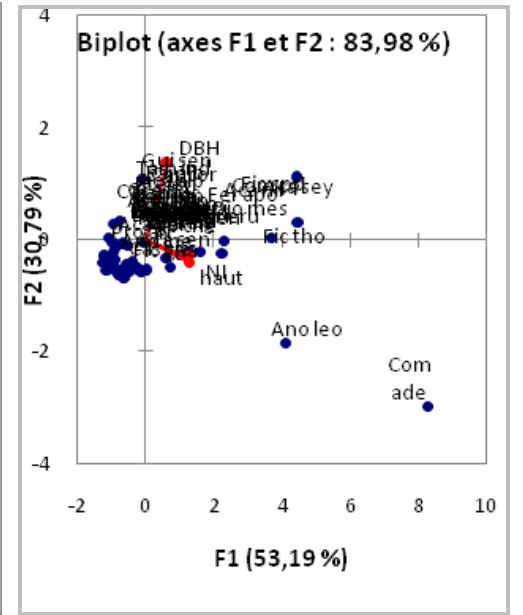

(b)

Fig. 12: Distribution according to dendrometric parameters (a) and dispersal of the woody (b). 
The principal component analysis done on species allowed us to understand the distribution of the species in the different plant formations. The representation of the species and sites on the factorial plan of F1, F2, F1 and F2 axes permits to regroup the species that are accidental and dominant in the sites. Indeed the species Anogeissus leiocarpus, Combretum adenogosum are the most representative of the study zone (Fig. 13). Following the F2 axis we observe a close relation between S3 and S2 which means a positive interrelationship between the overexploited savannas and the gallery forests which brought us to understand that these two formations are nearly characterized by identical species. As for the S1 and S4, we observe a difference with S3 and S2 which is to say that there is a negative interrelationship between the afforested savanna and the sacred forest. It is justified by the fact that the species of the afforested savanna are the new species introduced by the project of green sahel whereas the species of the sacred forest are the spontaneous species of the zone that are weakly threatened by anthropic activities.
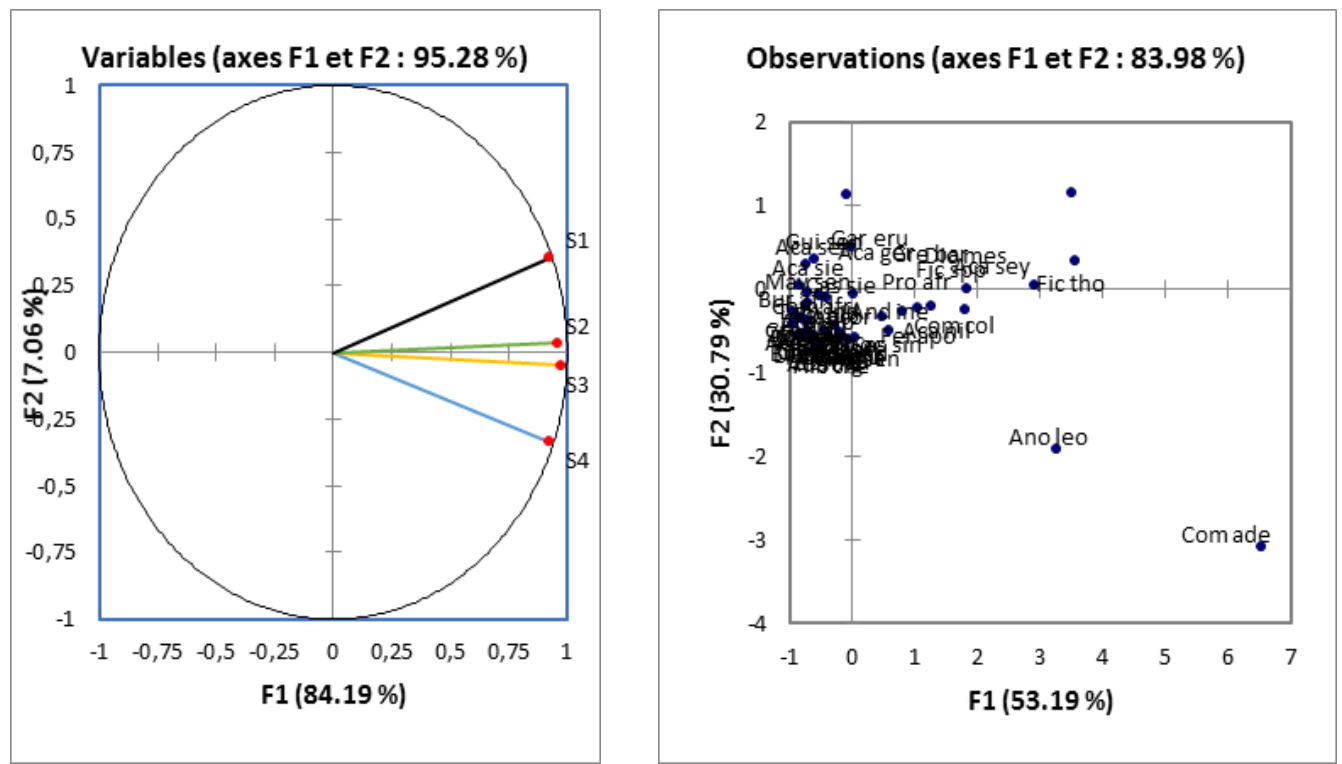

Fig. 13: The representation of the species and sites on the factorial plan: (a) Sites; (b) Species.

\section{Comparison of the different plant formations}

The four plant formations have some different floristic compositions. Results obtained reveal that there's a significant difference between the afforested savanna and the gallery forest $(64.14 \%)$. This value is weak between the forest gallery and the sacred forest (30.33\%), and between the overexploited savanna and the sacred forest $(31.2 \%)$. These weak values explain the likeness of the species that the sacred forest and the two other plant formations constitute, it is justified by the fact that the sacred forest is the component of the savanna and the gallery. The high index of Jaccard between the afforested savanna and the other plant formations justify the fact that the afforested savanna is constituted of exotic species that are introduced there by green sahel project. Consequently, the percentage of resemblance of these species with the other species is weak, and then the distance of Harming between the afforested savannas and sacred forests is $35.86 \%$, afforested savannas and gallery forests $21.8 \%$, afforested savannas and overexploited savannas $40.45 \%$ (Table 10).

Table 10. Comparison of the different plant formations (\%).

\begin{tabular}{lllllllll}
\hline & \multicolumn{2}{l}{ Afforestated savanna } & \multicolumn{2}{l}{ Sacred forest } & \multicolumn{2}{l}{ Forest gallary } & \multicolumn{2}{c}{ Overexploited savanna } \\
\cline { 2 - 9 } & TJ & $\mathbf{D H}$ & TJ & DH & TJ & DH & TJ & DH \\
\hline Afforestated savanna & $\mathbf{1 0 0}$ & $\mathbf{0}$ & 64.14 & 35.86 & 78.2 & 21.8 & 59.55 & 40.45 \\
Sacred forest & 64.14 & 35.86 & $\mathbf{1 0 0}$ & $\mathbf{0}$ & 30.33 & 69.66 & 31.2 & 68.8 \\
Gallery forest & 78.2 & 21.8 & 30.33 & 69.66 & $\mathbf{1 0 0}$ & $\mathbf{0}$ & 61.77 & 38.33 \\
Over exploited savanna & 59.55 & 40.45 & 31.2 & 68.8 & 61.77 & 38.33 & $\mathbf{1 0 0}$ & $\mathbf{0}$ \\
\hline
\end{tabular}


Different stages and strategies of sustainable management of plant formations in the Mayo-Kani Division -- Investigations on land and the state of natural resource management according to the villagers

The state and the management of the natural resources in this zone are determined by the lack of employment to occupy some people in order to succeed in providing their needs without touching the woody resources $(95.83$ \pm 1.18 a) followed by the lack of the popularization of other forms of domestic energy and the creation of other incomes generating activities apart from firewood (44.14 $\pm 11.61 \mathrm{~b}$ ) (Table11).There exists a significant difference between these doorstep investigations $(p>0.05)$.

Table 11. Land report on the three villages (\%).

\begin{tabular}{|c|c|c|c|c|}
\hline Investigation & Bipaing & Gabane & Gaboure & Total \\
\hline Lack of jobs to occupy some people in the villages & 97.5 & 95 & 95 & $95.83 \pm 1.18 \mathrm{a}$ \\
\hline $\begin{array}{l}\text { Lack of popularization of other forms of domestic energy and creation } \\
\text { of other income generating activities apart from firewood }\end{array}$ & 60 & 36.5 & 36 & $44.14 \pm 11.61 b$ \\
\hline Bad management of the protected areas & 26 & 32 & 23 & $27 \pm 3.74 a$ \\
\hline $\begin{array}{l}\text { Lack of the putting in place of all forms of associations producing } \\
\text { natural resources }\end{array}$ & 9 & 8 & 25 & $14 \pm 7.79 b$ \\
\hline Lack of forest services agents at the local level & 13 & 9 & 17 & $13 \pm 3.27 b$ \\
\hline $\begin{array}{l}\text { Lack of the sensitization of the native population on the stakes of } \\
\text { natural resources }\end{array}$ & 9 & 17 & 11 & $12.33 \pm 3.40 \mathrm{~b}$ \\
\hline
\end{tabular}

The figures affected by the same letters are not significant to the doorstep of $5 \%$.

Analysis of sustainable management strategy in the three villages

These analyses are done in two levels, at the level of natural resources and at the level socioeconomic context. At the natural resource level, the inventories showed that we disposed degraded plant formations (Fig. 6) indicating that $40 \%$ of the woody presents traces of cuts and $23.33 \%$ of pruning. The plant resources are under an anthropic pressure, due to the fact that those that exploit this vegetation are not organized and exploit without any strategy of sustainable management. It would have been necessary that we should organise exploiters in communities and drill them on techniques of sylviculturers, methods of afforestation and adjustment method. Also we can develop plant resources in these plant formations, and to ensure sustainable exploitation of firewood and wood work. When we will finish to develop plant resources, the wildlife will get settled alone. With regards to the socioeconomic context, the studies equally showed that some collectors are prepared to manage these plant formations. They are also prepared to manage them under the guide of the agents of Water and forests. Otherwise incomes got from the sale of firewood can at least feed some families (37\%) and assure some needs among the families of the collectors. The socioeconomic climate will probably facilitate the politic of participatory management, and consequently the sustainable management of the natural resources.

\section{A proposed adjustment plan for the management of natural resources}

\section{Measures in favor of the population}

The exploitation of the plant resources occupies an important place in the local collectivity. Table 12 presents adjustment methods of vegetation of the study zone by the native population. The populations contribute to the conservation of vegetation. The customary practices $(75 \%)$ constitute a most important means of conservation by the local population. The conservation of forest relics so-called sacred wood by the villagers for cultural or religious goals are practised by almost every population in villages: Bipaing (70\%), Gabane (80\%) and Gaboure (90\%). The organization of hunting and fishing $(46.67 \%)$ is the second means of biodiversity conservation in order to limit and to control the exploitation of the animal resources. To these two protective measures are added the introduction of species 
through the plantation of fruit trees $(43.33 \%)$, the creation of an agro-forest park system (26.67\%) for the maintenance of soil fertility or for the supply of the forest products. Contrary to the populations of the other villages, the population of Gaboure (12\%) doesn't actively contribute to the maintenance of biodiversity. The analysis of variance shows that there exists no meaningful difference between the methods undertaken by the local population. This time around it shows a significant difference between the villages $(0.00<0.05)$.

Table 12. Measures of co-management.

\begin{tabular}{lllll}
\hline Methods & Bipaing & Gabane & Gaboure & Average \\
\hline Plantation of fruit trees & 26.67 & 53.33 & 93.33 & $43.33 \pm 26.68^{\mathrm{a}}$ \\
Traditional regulation (Organization of hunting and fishing) & 40 & 76.67 & 70 & $46.67 \pm 24.65^{\mathrm{a}}$ \\
Custom practices (sacred woods) & 40 & 50 & 60 & $75 \pm 40.97^{\mathrm{c}}$ \\
Agroforestry parks & 14.33 & 17.67 & 64.66 & $26.67 \pm 17.70^{\mathrm{d}}$ \\
\hline
\end{tabular}

The figures affected by the same letters are not significant to the doorstep of $5 \%$

Measure concerning the government for the adjustment management of the natural resources in the Mayo-Kani Division

The hindrance of charcoal $(100 \%)$, sanctions for the illegal collectors $(100 \%)$, the hindrance of collecting green woods $(7.67 \%)$, the sensitization of the populations on the practice of bush fires $(100 \%)$ constitute the methods of management applied by the local population to limit the anarchical exploitation of the natural resources in order to assure their sustainability (Table13).

Table 13. Measure concerning the government for the management of natural resources.

\begin{tabular}{lllll}
\hline Measures for the management & Bipaing & Gabane & Gaboure & Moyenne \\
\hline Limitation of intensive agriculture & 0 & 0 & 0 & $0 \pm 0^{\mathrm{a}}$ \\
Hindrance of the charcoal production & 100 & 100 & 100 & $100 \pm 00 \mathrm{c}$ \\
Hindrance of the withdrawal of the & 6 & 8 & 9 & $7.67 \pm 1.53^{\mathrm{c}}$ \\
green woods & 100 & 100 & 100 & $100 \pm 00^{\mathrm{c}}$ \\
Sensitization on bush fire practices & 100 & 100 & 100 & $100 \pm 00^{\mathrm{c}}$ \\
Sanctions to the illegal reforestation operators & 100 & 100 & 100 & $100 \pm 00^{\mathrm{c}}$ \\
Creation of reserves & 18 & 20 & 21 & $19.67 \pm 1.53^{\mathrm{b}}$ \\
Use of improved homes & 56.5 & 54 & 52 & $54.17 \pm 3.12^{\mathrm{b}}$ \\
\hline
\end{tabular}

The figures affected by the same letters are not significant to the doorstep of 5\%.

In spite of everything, these adjustment strategies present some multiple weaknesses in the putting in place of their actions to know the absence of an adjustment plan, the concentration of the management by the service of conservation, the weak implication of the population in the management of vegetation, the penetration and the collection of resources without authorization, the strong pressure of the native population concerning the cutting of green woods. As regards these various problems encountered in the management of vegetation, numerous measures in a management plan have been taken.

\section{Diffusion and approval of the adjustment plan for the management of the natural resources in the Mayo- Kani Division}

A total of 4 measures have been retained by the government divided into 15 major points on orientation measures aimed at adjusting the progressive restoration of woody resources of vegetation while maintaining the activities of the different groups of farmers, breeders and traders of wood that have been using this space for years. Sanctions for charcoal producers $(100 \%)$, the increase of taxes on the sellers of natural resource products $(100 \%)$, the creation of the local brigades (96\%), the creation of the brigades against deforestation (96\%), re-afforestation (80\%), the development of a research project on the deforestation (68\%), the development of a participatory legislation (72\%), the creation of fire brigades (72\%) constitute the main propositions chosen by the government (Table 14). This variability is confirmed by the statistical analysis that reveals the existence of a highly meaningful difference between the averages of these various adjustment points kept by the government $(0.0064<0.05)$. Between the different ministries, significant differences do not exist $(p>0.05)$. 
Table 14. A proposed adjustment plan for plant formations in the Mayo-Kani Division.

\begin{tabular}{|c|c|c|c|c|c|c|}
\hline Propositions & MINAG & MINEPIA & MINEF & MINFOF & MINEPAT & Moyenne \\
\hline Reafforestation of species & 100 & 100 & 100 & 100 & 20 & $84 \pm 35.78^{b}$ \\
\hline Reglementation of 'exploitation of NWFP & 20 & 0 & 40 & 40 & 0 & $20 \pm 20.00^{\mathrm{e}}$ \\
\hline Sanctions of charcoal producers & 100 & 100 & 100 & 100 & 40 & $88 \pm 26.83^{b}$ \\
\hline Creation of local brigades against bush fires & 40 & 60 & 60 & 100 & 100 & $72 \pm 26.83^{\mathrm{a}}$ \\
\hline -Coordination for the fight against deforestation & 20 & 0 & 20 & 100 & 100 & $48 \pm 48.17^{\mathrm{c}}$ \\
\hline $\begin{array}{l}\text {-Increase of taxes for the sellers of natural } \\
\text { resources }\end{array}$ & 100 & 100 & 100 & 100 & 0 & $80 \pm 44.72^{b}$ \\
\hline $\begin{array}{l}\text {-Creation of local brigades to fight against } \\
\text { deforetation }\end{array}$ & 100 & 100 & 100 & 100 & 80 & $96 \pm 8.94^{b}$ \\
\hline -Development of a research on deforestation & 40 & 100 & 40 & 100 & 60 & $68 \pm 30.33^{\mathrm{a}}$ \\
\hline
\end{tabular}

The figures affected by the same letters are not significant to the doorstep of $5 \%$.

\section{Discussion}

The demographic explosion noted in the $\mathrm{XXI}^{\mathrm{st}}$ century has some repercussions on the state of vegetation in the sahelian zone. To satisfy the needs of this demography, the populations are sometimes obliged to exploit their natural resources in an intensive manner. They practise in an abusive manner the agricultural products and domestic energies. They also practise intensive agriculture, over grazing, bush fires and the cutting of wood. The savannas overexploited and the gallery forests are strongly attacked by agricultural activities and over grazing. Biba (2012) in the Adamawa region had shown that grazing presents depressive effects on vegetation whereas the MINEF (1994) proved rather that it is agriculture that occupies the first place in the economic activities of the Adamawa region. Schure et al. (2011) proved also that burn agriculture is the first cause of deforestation and forests degradation in central Africa. Other authors like Ntoupka (1998) and Tchobsala (2011) attested that the savannas of the sahelian zone are confronted with combined actions of bush fires, the cutting of wood and grazing that influence the wellbeing of ecosystems of the Far North and Adamawa regions respectively. The combined actions of these anthropic factors are the major reasons of the disappearance of the phytodiversity of our ecosystems.

In the Far North region, the species mostly used are Balanites aegyptiaca (100\%) in diet, Anogeissus leiocarpus (85\%) as firewood, Khaya senegalensis (35\%) for traditional medicines. These species are threatened and will disappear in this part of the country if nothing is done from here 2035.Wouldata (2012) showed that the abusive exploitation of the NWFP of plant origin in the Sahelian zone of Cameroon caused the bit by bit disappearance of trees in different plant formations. It is in this sense that Tchobsala (2011) affirms that the disappearance of the forest ecosystems through exploitation is the main reason of the increase in poverty. The consequences of this exploitation result from the modification of floristic composition of vegetation, the overexploitation has some effects even on the floristic diversity. Noiha et al. (2015) showed that the family of Ebenaceae is part of the families mostly represented in the Lobekele national park that is threatened with disappearance because of the phenomenon of anthropisation. This overexploitation of the natural resources also affects the vertical and horizontal structure of vegetation. Tchobsala (2011) and Tchobsala and Mbollo (2013) showed that vegetation is essentially constituted of individuals with diameter comprised between 10 and $20 \mathrm{~cm}$ in the urban periphery of Ngaoundéré. These results are different from those of Aoudou (2006) on the index of Shannon (3.68) and of the Equitability of Pielou (0.96) in the gallery forest of high Bénoué and is close to that of Tchobsala (2011) in the urban periphery of Ngaoundéré savannas where the Shannon index was weak. These weak indices in our study site are due to the presence of weak diversity species indicating a progressive regression of this vegetation. These results are contrary to those of Ntoupka (1999) in the Laf reserve in the SudanoSahelian which showed that the distances of Hamming between the different plant formations (farms, bushes and grazing land) are average. This difference would be due to the degree of anthropisation on the zones of study and especially of the different studied plant formations. Indeed, at the time that the savannas are overexploited, we have a weak specific wealth, it is the case of the savannas overexploited and the gallery forests. On the other hand, at the time that the savannas are either afforestated or protected as sacred forests or the access is forbidden the specific wealth is important. The global density of the woody species is decreasing significantly at the doorstep 5\% of the afforestated savanna and the sacred forests towards the gallery forests and the overexploited savannas. The best method of management 
of the natural resources resides in the co-management and the scheduling of adjustment plans.

Ntoupka (1999) in the Sudano-Sahelian zone of Laf demonstrated that populations are from being passive actors facing degradation through reforestation and the plantation of fruit trees. These results are in agreement with the measures taken by the government in notably the MINEF (1994) which encourages the protection of the environment through reforestation, the implication of the traditional authorities, religious and NGOs in the protection of sacred forests. The reforestation of green sahel sites of the Mayo-Kani Division is an asset for the reconstitution of the vegetation of the Division.

\section{Conclusion and perspectives}

At the end of this work which aimed to contribute to the assessment of the present state of vegetation in order to put in place the strategies of sustainable management of plant formations in the Sudano-Sahelian zone of Cameroon, it comes out again that three groups of people are integrated in the dynamics of this vegetation notably the local population, the administrative authorities and the local authorities. The main actors of exploitation of the natural resources are the farmers, collectors of nontimber forest products, breeders and hunters. The exploited products intervene in diet, traditional medicines, handicraft and trade. The species which are mostly used are Balanites aegyptiaca (100\%) for food, Anogeissus leiocarpus (85\%) as firewood, Khaya senegalensis (35\%) for traditional medicines. The consequences of this exploitation result in the modification of floristic composition of vegetation. The global density of the woody decreases significantly at the doorstep of $5 \%$ of the afforestated savanna and the sacred forests towards the gallery forests and the overexploited savannas. The investigations revealed that the communities of native villagers are most conscious of the regression state of vegetation. The persons responsible for the forest administration also discern the degradation of the woody resources in this zone through the extension of agricultural zones and the cutting of wood. Actions of repression and protective measures are done, but remain marginal in relation to the rate of exploitation. The collaboration between the forest administration, traditional authorities and the local staff of the development structures remained limited. The results of the study in this area confirm therefore the need to develop an adjustment plan in a participatory approach which accompaniment can be done by complementary initiatives of active development with the sense of a creation of a communal forest on the space delimited by the populations in the zone which is still relatively wooded. The study must be led in the sense of deepening the study on the ecological and floristic characteristics and put an emphasis on the dynamics in time and in the space of the animal and plant species and to make a study on the sequestration of the carbon in these different plant formations.

\section{Conflict of interest statement}

Authors declare that they have no conflict of interest.

\section{Acknowledgement}

We are anxious to thank ABIOGeT who financed this work. It is also very important for us to salute the voluntary manifestation of the MINEPDED for the support it brought to ABIOGeT for the financing of the green sahel sites for more than 10 years now. We will not finish our subject without acknowledging the part played by the native populations for the realization of this research work.

\section{References}

Aaron, M. P., Patricia, A. W., Caroline, E. R. L., Jan, E. R., Banfai, D. S., Louis, P. E., 2007. Savanna responses to feral buffalo in Kakadu National Park, Australia. Ecol. Monogr. 77(3), 441-463.

Antonios, P., 2002. Le développement agricole durable: rêve ou réalité ? Le courrier ACP-EU, 193, 28-29.

Aoudou, D. S., 2006. Dynamique du couvert végétale ligneux dans la haute vallée Bénouéau Nord-Cameroun. Thèse de doctorat, Université de Ngaoundéré.307p.

Biba, H. P., 2012. State of degradation and management of pastoral resources in pasture forage station Wakwa (Adamaoua, Cameroon). Memory Master II. 33p.

Carmenza, R., Blaser, J., Byrne, S., 2010. Le changement climatique: Quelles implications pour la gouvernance forestière? In: Gouverner les forêts africaines à l'ère de la mondialisation (Eds.: German, A.L., Karsenty, A., Tiani, A-M.). CIFOR, Bogor, Indonésie. pp.397-418.

Fotsing, E., 2009. Small Savannah: Un système d'information pour l'analyse intégrée des changements d'utilisation de l'espace à l'extrême-nord du Cameroun. Thèse de doctorat PhD, Université de Wageningen, Pays-Bas. 373p.

Daget, Ph., Poissonnet, J., 1971. Une méthode d'analyse phytologique des prairies. Ann. Agron. 22(1), 5-41.

Diop, E. H., 2000. Les biotechnologies et l'espoir de vaincre la famine et la malnutrition dans le monde. A Biotech. 4. 5p.

Donfack, P., 1998. Végétation des jachères du NordCameroun : typologie, diversité, dynamique et production. Thèse d'Etat. Université de Yaoundé. 270p.

Hien, V., Sedogo, P. M., Lompo, F., 1994. Gestion de la 
fertilité des sols au Burkina Faso: Bilan et perspectives pour la promotion de systèmes agricoles durables dans la zone soudano-Sahélienne (Eds.: Cattier, B.M., De Gorandi, V.C.). In: Séminaire Régional Organisé par la FAO et le CIRAD avec le Concours du Gouvernement Crançais, Dakar/Sénégal. pp.47-60.

Braun-Blanquet, J., 1928. Pflanzensoziologie. Grundzüge der Vegetationskunde, Biologische Studienbücher 7, Berlin. 330p.

FAO, 1997. State of the World's Forest. World End Publication, Oxford, UK. pp.1-5.

FAO, 2002. Report on the World's Soil Resource. 96p.

Lienou., 2003. Système hydrologique du yaéré (extrême-nord Cameroun), changement climatique et actions anthropiques: Consequence sur le bilan des transferts superficiels. In: Hydrology of the Mediteranean and Semiarid Region. Proceedings of International Symposium held at Montpellieravril 2003, ISHA Publ. pp.404-409.

MINADT, 2010. Enquête agricole au Cameroun. Manuel d'instruction aux Agents Recenseurs, Forme. 45p.

MINEF, 1994. Diagnostic général de la situation de l'environnement dans la province de l'Adamaoua. Document de base PNUD/GTZ/BM. 143p.

Moneze, A., 1990. Système de production et environnement. In : Gestion des ressources et des reserves de la Biosphère et éducation relative à l'environnement. Acte de SeminaireRegionale, republique du Cameroun-PNUDpatrimoine mondial- MAB. Samgmelima. 270p.

Ndam, N., 1998. Tree regeneration, vegetation dynamics and the maintenance of biodiversity on Mount Cameroon: the relative impact of natural and human disturbance. Thesis, University of Wales, Bangor, UK. 278 p.

Floch, E., 2007. Guide ROSELT/OSS pour l'étude et le suivi de la flore et de la végétation, Collection ROSELT/OSS, CT n ${ }^{\circ} 1$, Tunis. $175 \mathrm{p}$.

Noiha, N. V., Zapfack, L., Ngueguim, J. R., Tabue, M. R. B., Ibrahima, A., Mapongmetsem, P. M., 2015. Sequestered Standing Carbon Stock in Selective Exploited Timbers
Grown in Tropical Forest: a Case Study from the National Park of Lobeke (Cameroon). pp.21-22.

Ntoupka, M., 1998. Production utile de bois sous perturbation anthropique (pâturages et feux) dans la région soudanosahélienne du Nord Cameroun. Actes du colloque. La foresterie des zones sèches. Ouagadougou de Novembre 1998.12p.

Ntoupka, M., 1999. Influence des perturbations anthropiques (pâturages, feu et coupes de bois) sur la dynamique de la savane arbre en zone soudano-sahélienne du Nord Cameroun. 226p.

Ouédraogo, A., Thiombiano, A., Hahn-Hadjali, K., Guinko, S., 2003. Structure du peuplemen juvénile et potentialités de régénération des ligneux dans l'Est du Burkina Faso. Etudes sur la flore et la végétation du Burkina Faso et des pays avoisinants 10, 17-22.

Palmberg-Lerche, C., 1997. Vers un cadre cohérent pour la conservation et l'utilisation durable des ressources génétiques forestières. FAO, Rome. Ressour. Génét. Forestièr. 24, 16-20.

Schure, J., Ingram, V., Akalakou-Mayimba, 2011. Bois énergie en RDC: Analyse de la filière des villes de Kinshasa et Kisangani. Yaoundé, CIFOR, Projet Makala (http://makala.cirad.fr/).11p.

Tchobsala, 2011. Impact des coupes de bois sur la végétation naturelle de la zone péri-urbaine de Ngaoundéré (Adamaoua). Thèse de Doctorat Ph.D, Université e Yaoundé I. 204 p.

Tchobsala, Mbollo, M., 2013. Characterization and impact of Wood logging on plant formations in Ngaoundere District, Adamawa Région, Cameroon. J. Ecol. Natural Environ. 5(10), 265-277.

Wouldata, 2012. Produits Forestiers Non Ligneux d'origine végétale dans la zone sahélienne du Cameroun. Mémoire de Master Université de Maroua, Cameroun. 70p.

Zapfack, L., 2005. Impact de l'agriculture itinérante sur brulis sur la biodiversité végétale et la Séquestration du carbone. Thèse de docteur d'Etat .Université de Yaoundé I. 225p.

\section{How to cite this article:}

Tchobsala, Djallo, D., Adamou, I., Konsala, S., Clément, S., 2016. State, ecological characterization and strategies of sustainable management of plant formations in the Mayo-Kani Division (Far North Region, Cameroon). Int. J. Curr. Res. Biosci. Plant Biol. 3(9), 97-113. doi:http://dx.doi.org/10.20546/ijcrbp.2016.309.014 